\title{
16S rRNA Gene-Based Profiling of the Microbial Community in an Acid Mine Drainage Fe Precipitate at Libiola Mine (Liguria, Italy)
}

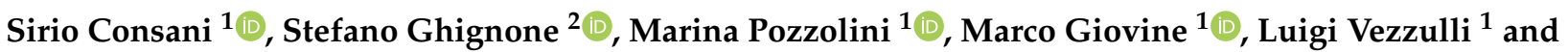 \\ Cristina Carbone ${ }^{1, *}$
}

check for updates

Citation: Consani, S.; Ghignone, S. Pozzolini, M.; Giovine, M.; Vezzulli,

L.; Carbone, C. 16S rRNA Gene-Based Profiling of the Microbial Community in an Acid Mine Drainage Fe

Precipitate at Libiola Mine (Liguria, Italy). Minerals 2021, 11, 1064. https://doi.org/10.3390/min11101064

Academic Editors:

Anna Panyushkina and

Maxim Muravyov

Received: 20 August 2021

Accepted: 22 September 2021

Published: 29 September 2021

Publisher's Note: MDPI stays neutral with regard to jurisdictional claims in published maps and institutional affiliations.

Copyright: (c) 2021 by the authors. Licensee MDPI, Basel, Switzerland. This article is an open access article distributed under the terms and conditions of the Creative Commons Attribution (CC BY) license (https:// creativecommons.org/licenses/by/ $4.0 /)$.
1 Department of Earth, Environment and Life Sciences (DISTAV), University of Genoa, I-16132 Genoa, Italy; sirio.consani@edu.unige.it (S.C.); marina.pozzolini@unige.it (M.P.); marco.giovine@unige.it (M.G.); luigi.vezzulli@unige.it (L.V.)

2 Institute for Sustainable Plant Protection (IPSP), SS Turin, National Research Council (CNR), I-10125 Turin, Italy; stefano.ghignone@ipsp.cnr.it

* Correspondence: cristina.carbone@unige.it; Tel.: +39-010-3538137; Fax: +39-010-352169

\begin{abstract}
Acid mine drainage (AMD) is a common environmental problem in many sulphide mines worldwide, and it is widely accepted that the microbial community plays a major role in keeping the process of acid generation active. The aim of this work is to describe, for the first time, the microbial community thriving in goethite and jarosite Fe precipitates from the AMD of the Libiola mine. The observed association is dominated by Proteobacteria $(>50 \%)$, followed by Bacteroidetes $(22.75 \%)$, Actinobacteria (7.13\%), Acidobacteria (5.79\%), Firmicutes (2.56\%), and Nitrospirae (1.88\%). Primary producers seem to be limited to macroalgae, with chemiolithotrophic strains being almost absent. A phylogenetic analysis of bacterial sequences highlighted the presence of heterotrophic bacteria, including genera actively involved in the AMD Fe cycle and genera (such as Cytophaga and Flavobacterium) that are able to reduce cellulose. The Fe precipitates constitute a microaerobic and complex environment in which many ecological niches are present, as proved by the wide range of bacterial species observed. This study is the first attempt to quantitatively characterize the microbial community of the studied area and constitutes a starting point to learn more about the microorganisms thriving in the AMD of the Libiola mine, as well as their potential applications.
\end{abstract}

Keywords: heterotrophs; Fe-oxidizing bacteria; extreme acidic environment; Proteobacteria; Acidobacteriaceae; jarosite and goethite

\section{Introduction}

Acidic discharge from mining areas is one of the most important sources of the contamination of surface waters and soils. Such acidic solutions, generally known as acid mine drainage (AMD), mainly derive from the dissolutive oxidation of the Fe sulphides pyrite and pyrrhotite, which are the most common and widespread sulphides present in ore deposits [1]. AMD is characterized by very low $\mathrm{pH}$ values (usually in the range between 2-3) and high concentrations of dissolved elements [2,3]. The oxidation of Fe sulphides is a complex phenomenon involving chemical, biological, and electrochemical reactions. The main oxidants of sulfides are $\mathrm{Fe}^{3+}$ ion under acidic conditions and dissolved oxygen at circumneutral $\mathrm{pH}$ because of the diminished solubility of $\mathrm{Fe}^{3+}$ [4]. In AMD, the dissolution of pyrite driven by the $\mathrm{Fe}^{3+}$ ion can be schematized according to the reaction:

$$
\mathrm{FeS}_{2}+14 \mathrm{Fe}^{3+}+8 \mathrm{H}_{2} \mathrm{O} \rightarrow 15 \mathrm{Fe}^{2+}+2 \mathrm{SO}_{4}{ }^{2-}+16 \mathrm{H}^{+}
$$

The oxidation of $\mathrm{Fe}^{2+}$ to $\mathrm{Fe}^{3+}$ by oxygen is T-dependent, but it is usually negligible [5], and the regeneration of the $\mathrm{Fe}^{3+}$ ion below $\mathrm{pH} 4$ is guaranteed by microbial organisms. 
Therefore, it is possible to state that acidophilic Fe-oxidizing microorganisms play a fundamental role in the processes of AMD formation [6].

Many microorganisms can be found in AMD, and this biodiversity is justified by the wide range of $\mathrm{pH}$, temperature, and oxygen content in AMD from site to site [7-9].

The majority of acidophiles are prokaryotic microorganisms, including a large variety of bacteria and archaea $[10,11]$. Dissolved $\mathrm{Fe}^{2+}$ is predominant in AMD and the majority of the microorganisms found in AMD exploit $\mathrm{Fe}^{2+}$ as an electron donor. Many of these Fe-oxidizing microorganisms act as pioneer primary producers in AMD waters, fixing $\mathrm{CO}_{2}$ into organic matter [7,12]. In the group of acidophilic Fe-oxidizing bacteria, it is possible to find highly specialized genera such as Leptospirillum, which only oxidizes $\mathrm{Fe}^{2+}$ in aerobic conditions, together with other bacteria such as Acidithiobacillus, which can grow in both aerobic and anaerobic conditions and which can use different energy sources [10].

In the microbial ecology of these peculiar environments, the presence of primary producers such as autotrophic bacteria and algae supports the stabilization of a large population of heterotrophic acidophiles. Many heterotrophs able to reduce $\mathrm{Fe}^{3+}$ [12] also belong to this community; they usually play a minor role in the geochemistry of AMD, whereas it is generally accepted that they contribute to creating a more suitable environment for the Fe-oxidizing bacteria by removing organic compounds that can be toxic [12].

Studies on the role of microorganisms in AMD are fundamental in the development of AMD management strategies. In addition, the scientific outcomes of this research are also relevant in the field of bioleaching, which is considered a mature hydrometallurgical technology for the recovery of metals [13]. This process is gaining increasing importance because it is cheaper than traditional roasting and smelting, and it is more environmentally friendly. Strains isolated from AMD are used for the extraction of many metals from minerals [13-15] and from artificial wastes such as fly ashes [16], oil-fired ashes [17], and steel slag [18]. Recently, a natural bacterial association dominated by Acidithiobacillus thiooxidans and Acidithiobacillus ferrooxidans was isolated from the Libiola mine area and used for hydrometallurgical purposes $[16,18]$. Other microorganisms isolated from the Libiola mine area, such as microfungi, were recently studied for their ability to uptake elements of interest [19]. Apart from the abovementioned study, no extensive characterization of the microbial community of the studied area has been performed. This paper aims, for the first time, to characterize the microbial community in the Fe-bearing precipitates of the Libiola AMD mine [20], giving a preliminary picture of the bacterial community of the area. The strongly interdisciplinary field of bio-geo-interactions, spanning from the microorganism to the mineral, holds much promise for future developments in both basic research and applied sciences.

\section{Materials and Methods}

\subsection{Study Area and Sampling}

The study area was the abandoned Libiola copper mine, located about $8 \mathrm{~km}$ NE of Sestri Levante (Eastern Liguria, Italy). The Libiola mine was already exploited in the sixteenth century, but evidence of ancient mining dating back to the early Copper Age (second half of the fourth millennium BC) has been observed [21]. In the modern age, official mining activity started in 1864 and ended in 1962, basically because of decreasing copper value and the high cost of infrastructural maintenance and repair. The mineralization is hosted inside basalts and consists of bodies of pyrite and chalcopyrite, with subordinate pyrrhotite and sphalerite, underlain by gabbros and serpentinites [22,23]. The mine complex develops over $30 \mathrm{~km}$ of underground excavations, 18 galleries and over 30 vertical shafts, and 3 major open pits. Inside the mine area, which extends over an area of approximately $4 \mathrm{~km}^{2}$ inside the catchment area of the Gromolo creek, five main waste-rock dumps and several minor deposits are located in proximity to the main mine adits. The sampling point $\left(44^{\circ} 18^{\prime} 32^{\prime \prime} \mathrm{N}\right.$, $9^{\circ} 26^{\prime} 32^{\prime \prime} \mathrm{E}$ ) is outside the longest tunnel in the mine area, called the Ida adit (Figure 1), and it is representative of Fe-rich AMD precipitates with very low $\mathrm{pH}$ values (generally 2.4-2.7). After $\approx 20 \mathrm{~m}$, these waters merge with the uncontaminated waters of the Gromolo creek 
near the confluence of the Rio Boeno, making this site very interesting for the evaluation of environmental conditions.

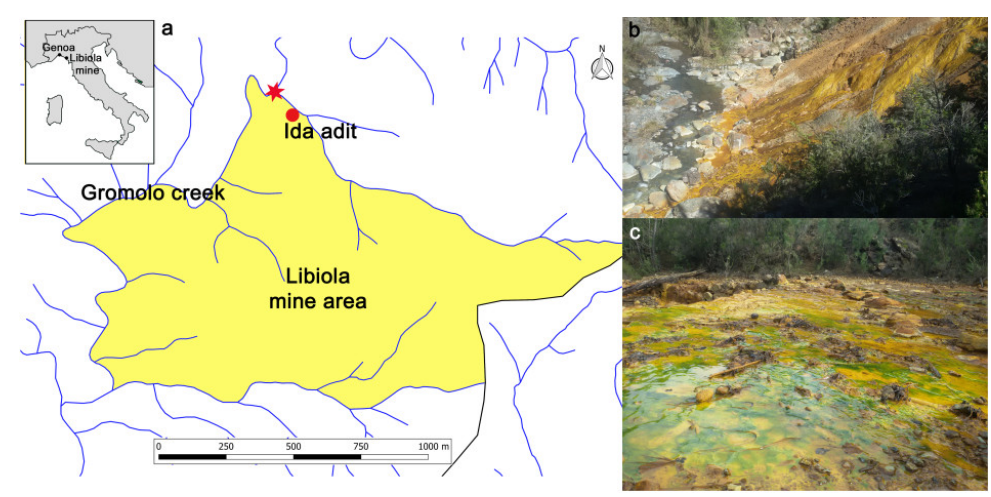

Figure 1. (a) Simplified sketch of the Libiola mine area and location of the Ida adit; red star and inset. (b) and merging with the uncontaminated waters of the Gromolo creek; red dot and inset. (c) location and picture of the sampling point of the precipitates (Ida adit).

The precipitate sample was collected by a plastic syringe, stored in polypropylene bottles, filtered through $16 \mu \mathrm{m}$ filters, and air-dried at room temperature. The $\mathrm{pH}$ of the AMD was measured in the field using a portable pH meter (WTW PH330i; Xylem Analytics, Weilheim, Germany).

To obtain the mineralogical composition of the sample, its XRD diagram was collected at the University of Copenhagen using a Bruker-AXS D8 Advance diffractometer (Bruker, Billerica, MA, USA) equipped with a primary-beam Ge111 monochromator, Cu tube (K $\alpha 1$ wavelength: $1.54059 \AA$ A) and a silicon-strip detector (Lynxeye, Bruker, Billerica, MA, USA). The pattern was collected in reflection Bragg-Brentano geometry between $2^{\circ}$ and $90^{\circ} 2 \theta$ with a step of $0.02^{\circ}$ and a measuring time of $4 \mathrm{~s} / \mathrm{step}$. The sample was mounted in rotating sample holders with a sample thickness of $2 \mathrm{~mm}$. To cut off fluorescence caused by high Fe concentration, the energy window of the detector was raised. The sample was air-dried and ground with an agate mortar and pestle to prepare it for chemical analyses. The concentration of Fe was determined by ICP-ES on $1 \mathrm{~g}$ of samples digested in hot aqua regia, whereas the concentration of all other elements ( $\mathrm{Al}, \mathrm{As}, \mathrm{Ca}, \mathrm{Co}, \mathrm{Cr}, \mathrm{Cu}, \mathrm{K}, \mathrm{Mg}, \mathrm{Mn}, \mathrm{Na}, \mathrm{Ni}$, $\mathrm{P}, \mathrm{Pb}, \mathrm{Ti}, \mathrm{V}$, and $\mathrm{Zn}$ ) was determined by ICP-MS on $0.5 \mathrm{~g}$ of sample after modified aqua regia digestion (ISO 15587) at Bureau Veritas Mineral Laboratories (Vancouver, BC, Canada).

\subsection{DNA Extraction and PCR}

For metagenomics analysis, $50 \mathrm{~mL}$ samples were collected in triplicate in sterile polypropylene tubes from the same site of the mineralogical analyses indicated in Figure 1 and frozen at $-20^{\circ} \mathrm{C}$ until the extraction of DNA. The genomic DNA of each sample was extracted with a Nucleospin soil kit (Macherey-Nagel GmbH \& Co. KG, Düren, Germany). The suspension present in the samples was first centrifuged for $10 \mathrm{~min}$ at room temperature at $2000 \times g$ and then to each $500 \mathrm{mg}$ of sediment present in the pellet were added $700 \mu \mathrm{L}$ of SL2 lysis buffer combined with $150 \mathrm{~mL}$ of SX Enhancer reagent, present in the extraction kit, directly in the NucleoSpin ${ }^{\circledR}$ Bead Tube. The samples were lysed in TissueLyser ${ }^{\circledR}$ (Qiagen, Hilden, Germany) for $5 \mathrm{~min}$ at $30 \mathrm{~Hz}$. The extraction steps were performed according to the manufacturer's instructions. Finally, the genomic DNA was eluted with $100 \mu \mathrm{L}$ of $80{ }^{\circ} \mathrm{C}$ pre-warmed $5 \mathrm{mM}$ Tris $/ \mathrm{HCl}, \mathrm{pH}$ 8.5. The extracted genomic DNA obtained from each $500 \mathrm{mg}$ of sediment was pooled and subjected to a phenol/chloroform/isoamyl alcohol further purification step, followed by absolute ethanol precipitation in the presence of $0.3 \mathrm{M}$ sodium acetate solution, $\mathrm{pH}$ 5.2. The final genomic DNA sample was resuspended in $100 \mu \mathrm{L}$ of $5 \mathrm{mM}$ Tris $/ \mathrm{HCl}, \mathrm{pH}$ 8.5. The DNA concentration was measured using a NanoDrop ND-1000 UV-Vis spectrophotometer (NanoDrop Technologies, Wilmington, DE, USA) and then stored at $-20^{\circ} \mathrm{C}$. Two hundred fifty nanograms of purified genomic DNA were run 
on $1 \%$ agarose gel to evaluate its integrity. To verify the presence of possible Polymerase Chain Reaction (PCR) inhibitors, $20 \mathrm{ng}$ of DNA were amplified using bacteria universal primers (27F: AGAGTTTGATCCTGGCTCAG and 1492R: GGYTACCTTGTTACGACTT) developed by [24]. The thermal profile was $95^{\circ} \mathrm{C}$ for $2 \mathrm{~min}$, followed by 25 cycles at $95{ }^{\circ} \mathrm{C}$ for $30 \mathrm{~s}, 55^{\circ} \mathrm{C}$ for $30 \mathrm{~s}$, and $72{ }^{\circ} \mathrm{C}$ for $60 \mathrm{~s}$, and extended at $72{ }^{\circ} \mathrm{C}$ for $5 \mathrm{~min}$.

Five micrograms of purified genomic DNA were finally used for sequencing the $16 \mathrm{~S}$ ribosomal DNA (rDNA) gene for taxonomic classification. The metagenomic sequencing library was prepared by PCR amplification of the V3 and V4 variable regions of the 16S rDNA gene from most of the groups of bacteria, using the universal primers set from Nadkarni et al. (2002) [25] 16S_univFor: 5'-CCTACGGGAGGCAGCAGT-3' and16S_univRev: 5'-GACTACCAGGGTATCTAATCCTGTT-3'). The pooled amplicon library was then sequenced on an Illumina MiSeq (Roche, Basel, Switzerland) platform with $2 \times 300 \mathrm{bp}$ chemistry by BMR Genomics Company (Padova, Italy).

\subsection{Sequence Analyses}

The initial reads' quality was checked with FastQC v. 0.11.5 [26]. PEAR v. 0.9.8 [27] was used to merge the forward and the reverse reads, first filtering the reads with a minimum quality score of 25 and allowing the reads to assemble when a minimum overlap of 10 base pairs occurred. The merged fragments were further filtered for quality and trimmed for length to increase the overall quality of the library. Trimmomatic v. 0.36 [28] was used to process the fragments. In this case, the quality of 25 was checked over a window of 10 nucleotides, and the minimum length was set to 250 base pairs.

The Quantitative Insights Into Microbial Ecology pipeline (Qiime, v. 1.9) [29] was used to perform the microbiome analysis, starting from processed DNA data. It was used first to further smooth the sequence quality, remove homopolymers, and trim the primers with an allowed mismatch of 4 . Then it was used to identity and remove chimeric sequences, using the program USEARCH v. 6 [30], implemented in the pipeline. The OTUs were built using a closed-reference strategy; entries from the Greengenes reference database v. 13.5 [31] were used as seeds to build clusters in which the sequences were $97 \%$ similar. The taxonomic affiliation was determined via BLAST method (e-value: 0.00001). Statistical downstream analyses were mostly performed within R [32], using vegan [33] and phyloseq [34] packages.

\section{Results}

\subsection{Mineralogical Characterization of the Sample}

The sample of AMD precipitates was collected immediately after red water emission from the Ida adit. The XRD diagram (Figure 2) highlights the presence of nanoscopic goethite $(\alpha-\mathrm{FeOOH})$ and jarosite $\left(\mathrm{KFe}_{3}\left(\mathrm{SO}_{4}\right)_{2}(\mathrm{OH})_{6}\right)$. These two minerals are commonly found in AMD, and their presence has already been reported in the studied area $[35,36]$.

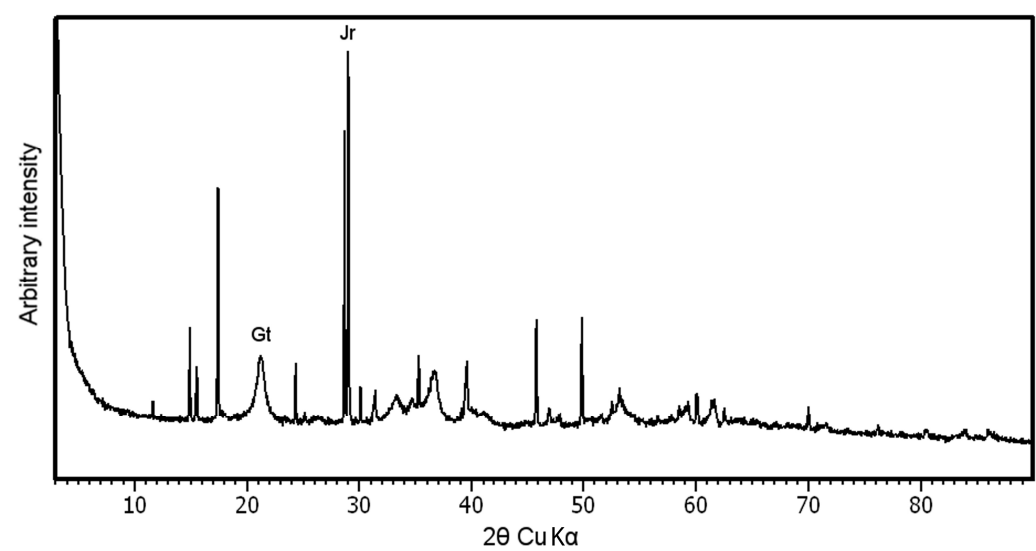

Figure 2. XRD pattern of a representative precipitate sample. $\mathrm{Gt}=$ goethite; $\mathrm{Jr}=$ jarosite. 
The bulk chemistry composition of the IDA sample is reported in Table 1 . The chemistry is dominated by Fe, which accounts for more than $50 \%$ of the sample. This is congruent with the observed mineralogical composition, which is completely composed of Fe-bearing minerals.

Table 1. Bulk chemistry of the precipitates collected from the Ida adit. n.a. = not analyzed.

\begin{tabular}{cccc}
\hline Element & $(\mathbf{w t} \%)$ & Element & $\left(\mathbf{m g} \cdot \mathbf{k g} \mathbf{g}^{-\mathbf{1}}\right)$ \\
\hline $\mathrm{Fe}$ & 50.69 & $\mathrm{Cu}$ & 2018 \\
$\mathrm{~S}$ & n.a. & $\mathrm{Zn}$ & 41 \\
$\mathrm{Al}$ & 0.06 & $\mathrm{Mn}$ & 77 \\
$\mathrm{Mg}$ & 0.03 & $\mathrm{Ni}$ & 11 \\
$\mathrm{Ca}$ & 0.04 & $\mathrm{Cr}$ & 96 \\
$\mathrm{Ti}$ & 0.02 & $\mathrm{~V}$ & 64 \\
$\mathrm{Na}$ & 0.01 & $\mathrm{As}$ & 4.30 \\
$\mathrm{~K}$ & 0.05 & $\mathrm{~Pb}$ & 2 \\
$\mathrm{P}$ & 0.01 & $\mathrm{Co}$ & 2 \\
\hline
\end{tabular}

The $\mathrm{Al}$ concentration is quite low, likely because the measured $\mathrm{pH}$ in the sampling site (2.6) was below the first solubility constant of $\mathrm{Al}$, thus preventing its incorporation in the solid phase. Other elements have concentrations one order of magnitude smaller, with only $\mathrm{K}$ reaching high relative concentrations, reflecting the presence of jarosite. The concentrations of trace elements are quite low, with only $\mathrm{Cu}$ reaching $2018 \mathrm{mg} \cdot \mathrm{kg}^{-1}$. All other trace elements are below $100 \mathrm{mg} \cdot \mathrm{kg}^{-1}$.

\subsection{Genomic DNA Extraction, Microbial Diversity, and Richness in AMD Precipitates}

Using a Nucleospin soil kit (Macherey-Nagel GmbH \& Co. KG) with the combination of SL2 lysis buffer/SX Enhancer reagent, it was possible for the lysis step to isolate genomic DNA from the AMD precipitates with a yield of $0.38 \mu \mathrm{g} \cdot \mathrm{g}^{-1}$. In order to obtain purified genomic DNA suitable for the PCR amplification protocol, a further phenol/chloroform/isoamyl alcohol purification was necessary. Starting from $5 \mu \mathrm{g}$ of purified genomic DNA, the Illumina MiSeq sequencing gave 1,161,981 paired-end reads. Both of the pair reads showed a decreasing quality toward the $3^{\prime}$ end of the fragments, which made the proper assembly toward the ends of the fragments challenging. The PEAR software was able to assemble $94.864 \%$ of the reads, producing 1,102,304 useful assembled fragments, with a sequence length ranging from 57 to $589 \mathrm{bp}$. After the process with Trimmomatic, a final collection of 756,025 sequences, whose lengths spanned from 250 to $500 \mathrm{bp}$, was obtained. Before OTUs assembly, Qiime was used to refine the sequence collection, including the removal of 89,505 sequences recognized as chimeric. At the end of the process, Qiime produced a total of 615,535 useful sequences for Operation Taxonomic Unit (OTU) picking. The identification of the bacterial community was also performed down to the genus level, when possible. The 10 most abundant genera are reported in Table 2, whereas the complete list of the observed bacteria is given in the Supplementary Materials (Online Resource 1).

The analysis of the microbiota highlighted the presence of 3094 OTUs, 743 of which were represented by more than 10 sequences. The taxonomic affiliation of the 743 OTUs was performed comparing the observed OTUs with known bacteria marker sequences, and their phylum distribution is reported in Figure 3. The association is dominated by bacteria, in particular by Proteobacteria, which accounted for more than $50 \%$ of the assemblage, followed by Bacteroidetes (22.75\%), Actinobacteria (7.13\%), Acidobacteria $(5.79 \%)$, Firmicutes $(2.56 \%)$, and Nitrospirae (1.88\%). All other phyla were detected with a relative abundance below $0.50 \%$ with almost all of them being counted only once. A single OTU related to an archaea belonging to the phylum Euryarchaeota $(0.13 \%$ or relative abundance) was observed. These particular archaea were already identified in AMD waters in [37]. 
Table 2. Genus and relative abundance of the ten most present OTUs.

\begin{tabular}{cc}
\hline Genus & Relative Abundance (\%) \\
\hline Flavobacterium & 5.11 \\
undetermined_Comamonadaceae & 5.11 \\
undetermined_Acidobacteriaceae & 4.44 \\
Unclassified & 3.90 \\
undetermined_Acetobacteraceae & 3.77 \\
undetermined_Acidimicrobiales & 3.63 \\
undetermined_Sphingobacteriales & 3.50 \\
Novosphingobium & 3.10 \\
undetermined_Oxalobacteraceae & 3.10 \\
Pedobacter & 2.96 \\
\hline
\end{tabular}

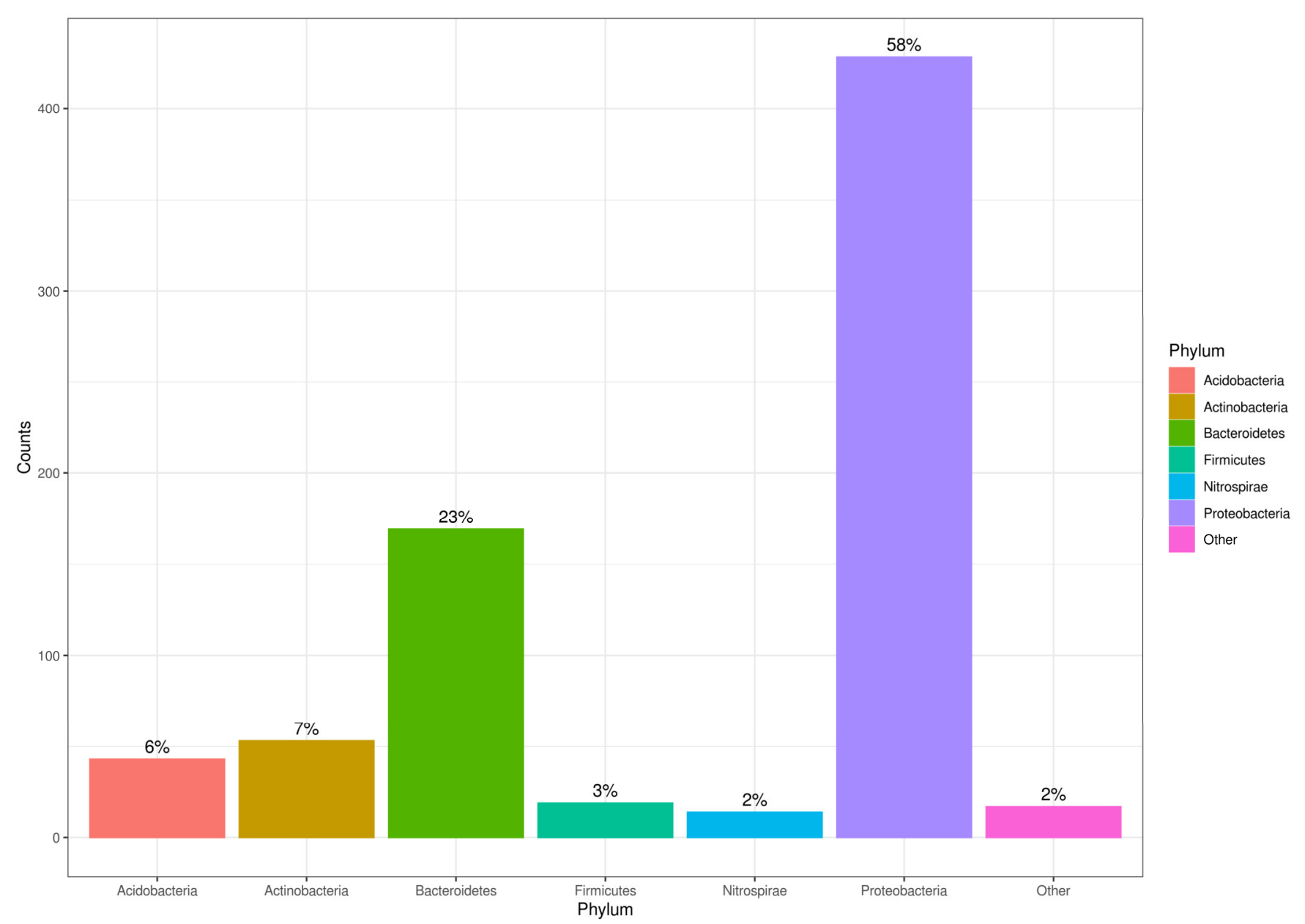

Figure 3. Bar plot of the phylum distribution in the Fe precipitates from the Ida adit. Phyla with less than 10 total counts are merged in "Other".

\section{Discussion}

Usually, AMD-related bacterial communities are dominated by one or two strains, as this environment is highly selective and challenging. On the contrary, in the assemblage of the Libiola mine, a clear dominance of one strain is lacking. A similar diffusion of taxa was observed in [38], and the lack of a clearly dominating species was detected in an AMD assemblage from the Jinkouling tailing pond in China ( $\mathrm{pH}$ of 2.65), as reported in [11]. Although the genera from the Chinese bacterial community are quite different from the ones observed in the Ida adit community, both are dominated by Proteobacteria, followed by Bacterioidetes and a different abundance of Nitrospirae and Actinobacteria. 
Another similar bacterial association was observed in AMD from Spain. Members of the Actinobacteria, Acidobacteria, Planctomycetes, Firmicutes, and Chloroflexi phyla were identified in sediments of the Tinto basin, whereas samples from three boreholes in Peña de Hierro, analyzed by catalysed reporter deposition-fluorescence in situ hybridization (CARD-FISH) using complementary probes, showed positive hybridization signals for both bacteria and archaea, with Proteobacteria as the most representative bacterial phylum, followed by Actinobacteria, Acidobacteria, and Firmicutes [39].

The bacterial association of the Fe precipitates is quite different from the usual ones reported from AMD environments. The distribution of OTUs within different genera is diffused, with the most abundant genera (Flavobacterium sp. and Comamonadaceae sp.) representing $5.11 \%$ of the total bacterial population. Undetermined Acidobacteriaceae, Acetobacteraceae, and Acidimicrobiales followed with relative abundancy in the range of $4.44-3.63 \%$.

Generally, in AMD, primary producers are dominant. Chemiolithotrophic Fe- and S- oxidizing bacteria such as Acidithiobacillus and Leptospirillum (with the latter being able to oxidize only $\mathrm{Fe}$ ) are the most present genera, and in regions of the system exposed to sunlight, photosynthesis may be an important source of energy and fixed carbon [40]. In fact, most subsurface AMD sites receive relatively minimal inputs of fixed carbon and nitrogen from external sources, and therefore heterotrophs are not widespread. Both Acidithiobacillus and Leptospirillum have a low concentration in Fe precipitates from the Ida adit $(0.81 \%$ and $1.88 \%$, respectively). Often, Acidithiobacillus spp. are numerically dominant among autotrophic Fe-oxidizing bacteria in freshly discharged $\mathrm{Fe}^{2+}$ - and Fe-rich waters, whereas Leptospirillum becomes increasingly significant downstream as $\mathrm{Fe}^{2+}$ concentrations fall and soluble $\mathrm{Fe}^{3+}$ concentrations increase [1]. The relative concentration of autotrophic S-oxidizing bacteria is even lower, with the genera Thiobacillus, Thiomonas (members of this genus can also grow as heterotrophs using organic carbon), and Thermomonas having only one single OTU identified (relative abundance of $0.13 \%$ each). Thiomonas spp. are moderate, rather than extreme, acidophiles and are generally not found in extremely acidic and metalrich mine waters. Authors in [1,6] proposed that extremely acidophilic prokaryotes such as Acidithiobacillus and Leptospirillum may have only a minor (if any) role in some AMDs. Previously unknown "moderately acidophilic" Fe- (and S-) oxidizing bacteria appear to be more significant, particularly in waters of $\mathrm{pH}>3$. The $\mathrm{pH}$ values of red waters in the Ida adit are generally in the range of 2.6-2.8 (i.e., close to 3). Some moderately acidophilic bacteria can also catalyze the reduction of $\mathrm{Fe}^{3+}$ in aerobic cells, as has been observed in Fe-rich sediments [6]. Nonetheless, it is worth noting that Leptospirillum can play a major role in $\mathrm{N}$ fixation in some AMD [41], and bioavailable nitrogen can be a growth-limiting factor in AMD environments.

Primary production in this site seemed to be guaranteed by macroalgae, which are widely present in the sampled area (Figure 1c). Instead of primary-producer bacteria, a variety of heterotrophic microbes were observed with PCR. This abundance of heterotrophs might be explained by both the characteristics of the bacteria and by the presence of different sources of organic carbon, such as vegetal litter and macroalgae (Figure 1c). A similar observation was made by Rowe et al. [37], who observed a heterotroph bloom concomitant with algal biomass in a streamer/mat from the Cantareras mine AMD.

Among Acetobacteriaceae (3.77\%) it is possible to find some acidophilic heterotrophs, mainly of the genus Acidiphilium, able to reduce $\mathrm{Fe}^{3+}$ both in the soluble and solid phase, even in the presence of oxygen [42]. This ability to reduce Fe will regenerate soluble $\mathrm{Fe}^{2+}$, which will again be oxidized by Fe-oxidizing bacteria, creating a cycle. Acidiphilium spp. are very metabolically versatile strains, as they also have the ability to oxidize S or Fe(II) [43]. Among the bacteria identified in Fe precipitates from the Ida adit, many different moderate acidophilic heterotrophs were recognized, with some of them also able to reduce $\mathrm{Fe}^{3+}$. Acidobacteria spp., present with a relative abundance of $5.79 \%$, populate relatively moderate AMD environments $\left(20-37^{\circ} \mathrm{C}\right.$ and $\left.\mathrm{pH} 3.0-6.0\right)$. Authors in [44] concluded that at the Richmond mine site, this group is limited to higher-pH environments. Some members 
of the Acidobacteriaceae family, isolated from mine waters, have been shown to reduce $\mathrm{Fe}^{3+}$ [45]. Moreover, Acidobacteriia, the most common class of Acidobacteria in low-pH environments, is composed of well-known metal-tolerant strains able to participate in the redox cycle of a variety of metals and metalloids, such as As, Cr, and $\mathrm{Hg}[43,46]$.

Among Actinobacteria (7.13\%), some species (e.g., Ferrimicrobium acidiphilum (Fm, a Gram-positive Actinobacterium)) are obligate heterotrophs and obtain energy from the oxidation of $\mathrm{Fe}^{2+}$ and carbon from an organic source [1]. Acidimicrobium ferrooxidans is also a Gram-positive Actinobacterium, but in contrast to mesophilic Ferrimicrobium this Feoxidizing bacterium is a moderate thermophile and therefore of more limited distribution in most mine-impacted waters.

Hallberg and Johnson [6] isolated and cultured bacteria from AMD, and many exhibited the typical colony morphologies of the acidophilic heterotrophs that belong to the genera Acidocella (0.94\%) and Acidiphilium (1.08\%). As previously reported, all characterized Acidiphilium spp. have been shown to catalyze the dissimilatory reduction of $\mathrm{Fe}^{3+}$, and they appear to do this more proficiently when grown under microaerobic, as opposed to strictly anoxic, conditions [6,39]. This genus is widely distributed in mine waters [1], and some species can also accelerate the oxidation of reduced $S$, though only when provided with organic carbon. In particular, A. acidophilum is an acidophilic S-oxidizing bacterium that is capable of growing as a heterotroph (a trait that characterizes all other known species of Acidiphilium), but it can also grow autotrophically, using reduced $\mathrm{S}$ as an energy source.

Among the spore-forming Firmicutes phylum (2.56\%), a number of species of Grampositive Fe- and S-oxidizing acidophilic bacteria have been described. Even if most of these microorganisms are thermotolerant or moderately thermophilic and would not be expected to thrive in most mine waters, some unclassified species (possibly belonging to novel genera) have also been detected in low-temperature mine waters [47]. Among the unidentified Comamonadaceae sp. (5.11\%), the presence of facultative anaerobes, the Fe-oxidizing genus Acidovorax already observed in AMD [38,39], could not be excluded.

Forster and colleagues [48] observed the presence of Flavobacteria (5.11\%), Pseudomonas $(0.40 \%)$, and Cytophaga (3.50\%) genera in AMD-impacted waters in Alaska. In particular, Flavobacteria and Cytophaga were observed with sulphate-reducing bacteria (practically not present in the Ida adit association), indicating that these bacteria are able to grow even in reducing conditions. Moreover, Cytophaga have a cellulose-degrading capability [49], supporting the fact that organic litter and macroalgae may play a role in the establishment of this community. The only OTU $(0.13 \%)$ able to reduce $S$ found in the Fe precipitates of the Ida adit is Sulfurospirillum sp.

The environmental conditions suggested by the bacterial assemblage observed in Fe precipitates from the Ida adit seem to point to a microaerobic environment with low oxygen. A complete anoxic, reducing environment seems to be excluded, both for the absence of S-reducing bacteria and for the presence of obligate aerobic bacteria such as Leptospirillum sp. However, it is not possible to exclude that the presence of Leptospirillum sp. might derive from a different bacterial association thriving in the oxidative, aerobic acid waters of the Ida adit. A similar difference in the conditions between sediments and waters was observed also in Río Tinto, an AMD-impacted river in the Iberian Pyrite Belt. Amils [39] reported that an aerobic metabolism was detected in the water column of the river, whereas most of the microbial activities in sediments, biofilms, and in the subsurface of the Río Tinto operate in anoxic conditions similar to those existing inside bioleaching heaps. These differences prove that, in a semisolid matrix such as sediments, with different microniches that permit diverse environmental conditions, antithetic metabolisms can operate, whereas this is not possible in a homogeneous water column [39].

\section{Conclusions}

The Fe precipitates of the Libiola mine showed a complex environment in which it was possible to find a great diversity of bacteria. The main primary producers supporting the community were probably photosynthetic macroalgae, with Fe- and S-autotrophic 
oxidizing strains being present in low abundance. This primary production supports a wide range of heterotrophic bacteria which seem to control the cycle of Fe and S, and it is not possible to completely exclude that such bacteria also control the chemical cycle of other metals and metalloids. Heterotrophic bacteria communities are divided into strains able to participate in the Fe cycle in AMD and strains able to degrade organic matter, likely supplied by macroalgae and litter. These results highlight a remarkable lack of dominance of some specific microorganism species, suggesting the co-existence of many different microenvironments colonized by associations of bacteria with different ecological specificity. This study is of great importance and represents the beginning of further investigations for bioleaching applications to recover $\mathrm{Cu}$ from the Libiola mine dumps using autochthonous microbial strains.

Supplementary Materials: The following are available online at https:/ /www.mdpi.com/article/10 $.3390 / \mathrm{min} 11101064 / \mathrm{s} 1$, Online Resource 1 csv. file.

Author Contributions: Conceptualization, S.C. and C.C.; methodology, S.C. and M.P.; software, S.G.; formal analysis, S.C. and M.P.; investigation, S.C. and C.C.; resource, C.C.; data curation, S.C., M.P. and S.G.; writing—original draft preparation, S.C.; writing—review and editing, S.C., M.P., S.G. and C.C.; supervision, C.C., M.G. and L.V.; project administration, C.C.; funding acquisition, C.C. All authors have read and agreed to the published version of the manuscript.

Funding: This research was funded by Cristina Carbone, FRA (Fondi di Ricerca Ateneo), University of Genova, and the APC was funded by Cristina Carbone.

Data Availability Statement: The sequence dataset generated for this study has been deposited in the NCBI Sequence Read Archive (SRA-NCBI; https:/ / www.ncbi.nlm.nih.gov/sra) under BioProject accession number PRJNA762026 and BioSample accession number SAMN21368742.

Acknowledgments: The authors would like to thank Arturo Corti (mine owner), who allowed us to conduct the field campaign around the Libiola mine area. Tonci Balić-Žunić is gratefully acknowledged for the X-ray diffraction analysis and his support.

Conflicts of Interest: The authors declare no conflict of interest.

\section{References}

1. Blowes, D.W.; Ptacek, C.J.; Jambor, J.L.; Weisener, C.G.; Paktunc, D.; Gould, W.D.; Johnson, D.B. The geochemistry of acid mine drainage. In Treatise of Geochemistry, 2nd ed.; Elsevier: Amsterdam, The Netherlands, 2014; Volume 11, pp. 131-190.

2. Nordstrom, D.K.; Alpers, C.N. Geochemistry of Acid Mine Waters. In The Environmental Geochemistry of Mineral Deposits, Part A; Plumlee, G.S., Longdon, M.J., Eds.; Society of Economic Geologists Inc.: Littleton, CO, USA, 1999; pp. $133-157$.

3. Ritchie, A.I.M. The waste-rock environment. In Short Course Handbook on Environmental Geochemistry of Sulfide Mine-Waste; Jambor, J.L., Blowes, D.W., Eds.; Mineralogical Association of Canada: Ottawa, QC, Canada, 1994; pp. 133-162.

4. Singer, P.C.; Stumm, W. Acid mine drainage-rate determining step. Science 1970, 167, 1121-1123. [CrossRef] [PubMed]

5. Stumm, W.; Morgan, J.J. Aquatic Chemistry, 3rd ed.; Wiley: New York, NY, USA, 1996; p. 1040.

6. Hallberg, K.B.; Johnson, D.B. Novel acidophiles isolated from moderately acidic mine drainage waters. Hydrometallurgy 2003, 71, 139-148. [CrossRef]

7. Hallberg, K.B. New perspectives in acid mine drainage microbiology. Hydrometallurgy 2010, 104, 448-453. [CrossRef]

8. Korehi, H.; Blothe, M.; Schippers, A. Microbial at the moderate acidic stage in three different sulfidic mine tailings dumps generating acid mine drainage. Res. Microbiol. 2014, 165, 713-718. [CrossRef]

9. Bomberg, M.; Makinen, J.; Salo, M.; Kinnunen, P. High diversity in iron cycling microbial communities in acidic iron-rich water of Pyhasalmi mine, Finland. Geofluids 2019, 1-17. [CrossRef]

10. Johnson, D.B. Extremophiles: Acidic Environments. In Encyclopedia of Microbiology, 3rd ed.; Schaechter, M., Ed.; Academic Press: Cambridge, MA, USA; Elsevier: Amsterdam, The Netherlands, 2009; pp. 107-126.

11. Yang, Y.; Li, Y.; Sun, Q. Archaeal and bacterial communities in acid mine drainage from metal-rich abandoned tailing ponds, Tongling, China. Trans. Nonferr. Met. Soc. China 2014, 24, 3332-3342. [CrossRef]

12. Johnson, D.B.; Hallberg, K.B. Carbon, iron and sulfur metabolism in acidophilic micro-organisms. Adv. Microb. Physiol. 2008, 54, 201-255.

13. Rodrigues, M.L.M.; Lopes, K.C.S.; Leôncio, H.C.; Silva, L.A.M.; Leão, V.A. Bioleaching of fluoride-bearing secondary copper sulphides: Column experiments with Acidithiobacillus ferrooxidans. Chem. Eng. J. 2016, 284, 1279-1286. [CrossRef]

14. Orell, A.; Navarro, C.A.; Arancibia, R.; Mobarec, J.C.; Jerez, C.A. Life in blue: Copper resistance mechanisms of bacteria and Archaea used in industrial biomining of minerals. Biotech. Adv. 2010, 28, 839-848. 
15. Watling, H.R. Chalcopyrite hydrometallurgy at atmospheric pressure: 1. Review of acidic sulfate, sulphate-chloride and sulphate-nitrate process options. Hydrometallurgy 2013, 140, 163-180. [CrossRef]

16. Funari, V.; Mäkinen, J.; Salminen, J.; Braga, R.; Dinelli, E.; Revitzer, H. Metal removal from Municipal Solid Waste Incineration fly ash: A comparison between chemical leaching and bioleaching. Waste Manag. 2017, 60, 397-406. [CrossRef]

17. Rastegar, S.O.; Mousavi, S.M.; Shojaosadati, S.A.; Sarraf Mamoory, R. Bioleaching of V, Ni, and Cu from residual produced in oil fired furnaces using Acidithiobacillus ferrooxidans. Hydrometallurgy 2015, 157, 50-59. [CrossRef]

18. Gomes, H.I.; Funari, V.; Mayes, W.M.; Rogerson, M.; Prior, T.J. Recovery of Al, Cr and V from steel slag by bioleaching: Batch and column experiments. J. Environ. Manag. 2018, 222, 30-36. [CrossRef]

19. Di Piazza, S.; Cecchi, G.; Cardinale, A.M.; Carbone, C.; Mariotti, M.G.; Giovine, M.; Zotti, M. Penicillium expansum Link strain for a biometallurgical method to recover REEs from WEEE. Waste Manag. 2017, 60, 596-600. [CrossRef] [PubMed]

20. Carbone, C.; Di Benedetto, F.; Marescotti, P.; Martinelli, A.; Sangregorio, C.; Cipriani, C.; Lucchetti, G.; Romanelli, M. Genetic evolution of nanocrystalline Fe oxide and oxyhydroxide assemblages from the Libiola Mine (eastern Liguria, Italy): Structural and microstructural investigations. Eur. J. Mineral. 2005, 17, 785-795. [CrossRef]

21. Maggi, R.; Pearce, M. Mid fourth-millennium copper mining in Liguria, north-west Italy: The earliest known copper mines in Western Europe. Antiquity 2005, 79, 66-77. [CrossRef]

22. Garuti, G.; Zaccarini, F. Minerals of Au, Ag, and U in volcanic rock-associated massive sulfide deposits of the Northern Apennine ophiolite, Italy. Can. Mineral. 2005, 43, 935-950. [CrossRef]

23. Zaccarini, F.; Garuti, G. Mineralogy and chemical composition of VMS deposits of northern Apennine ophiolites, Italy: Evidence for the influence of country rock type on ore composition. Mineral. Petrol. 2008, 94, 61-83. [CrossRef]

24. Lane, D.J. 16S/23S rRNA sequencing. In Nucleic Acid Techniques in Bacterial Systematics; Stackebrandt, E., Goodfellow, M., Eds.; Wiley: Hoboken, NJ, USA, 1991; pp. 115-175.

25. Nadkarni, M.A.; Martin, F.E.; Jacques, N.A.; Hunter, N. Determination of bacterial load by real-time PCR using a broad-range (universal) probe and primers set. Microbiology 2002, 48, 257-266. [CrossRef] [PubMed]

26. Andrews, S. FastQC: A Quality Control Tool for High Throughput Sequence Data. 2010. Available online: http://www. bioinformatics.babraham.ac.uk/projects (accessed on 24 January 2020).

27. Zhang, J.; Kobert, K.; Flouri, T.; Stamatakis, A. PEAR: A fast and accurate illumina paired-end reAd mergeR. Bioinformatics 2013, 30, 614-620. [CrossRef] [PubMed]

28. Bolger, A.M.; Lohse, M.; Usadel, B. Trimmomatic: A flexible trimmer for illumina sequence data. Bioinformatics 2014, 30, 2114-2120. [CrossRef] [PubMed]

29. Caporaso, J.G.; Kuczynski, J.; Stombaugh, J.; Bittinger, K.; Bushman, F.D.; Costello, E.K.; Fierer, N.; Peña, A.G.; Goodrich, J.K.; Gordon, J.I.; et al. QIIME allows analysis of high-throughput community sequencing data. Nat. Methods 2010, 7, 335-336. [CrossRef] [PubMed]

30. Rognes, T.; Flouri, T.; Nichols, B.; Quince, C.; Mahé, F. VSEARCH: A versatile open source tool for metagenomics. PeerJ 2016, 4, e2584. [CrossRef] [PubMed]

31. McDonald, D.; Price, M.N.; Goodrich, J.; Nawrocki, E.P.; DeSantis, T.Z.; Probst, A.; Andersen, G.L.; Knight, R.; Hugenholtz, P. An improved greengenes taxonomy with explicit ranks for ecological and evolutionary analyses of bacteria and archaea. ISME J. 2012, 6, 610-618. [CrossRef] [PubMed]

32. R Core Team. R: A Language and Environment for Statistical Computing. R Foundation for Statistical Computing: Vienna, Austria. 2020. Available online: https:/ /www.R-project.org/ (accessed on 24 January 2020).

33. Oksanen, J.F.; Blanchet, G.; Friendly, M.; Kindt, R.; Legendre, P.; McGlinn, D.; Minchin, P.R.; O’Hara, R.B.; Simpson, G.L.; Solymos, P.; et al. Vegan: Community Ecology Package. R Package Version 2.4-4. 2017. Available online: https://CRAN.R-project.org/ package=vegan (accessed on 25 January 2020).

34. McMurdy, P.J.; Holmes, S. Phyloseq:an R package for reproducible interactive analysis and graphics of microbiome census data. PLOS ONE 2013, 8, e61217.

35. Carbone, C.; Dinelli, E.; Marescotti, P.; Gasparotto, G.; Lucchetti, G. The role of AMD secondary minerals in controlling environmental pollution: Indications from bulk leaching tests. J. Geochem. Explor. 2013, 132, 188-200. [CrossRef]

36. Consani, S.; Ianni, M.C.; Dinelli, E.; Capello, M.; Cutroneo, L.; Carbone, C. Assessment of metal distribution in different Fe precipitates related to Acid Mine Drainage through two sequential extraction procedures. J. Geochem. Explor. 2019, 196, 247-258. [CrossRef]

37. Rowe, O.F.; Sánchez-España, J.; Hallberg, K.B.; Johnson, D.B. Microbial communities and geochemical dynamics in an extremely acidic, metal-rich stream at an abandoned sulfide mine (Huelva, Spain) underpinned by two functional primary production systems. Environ. Microbiol. 2007, 9, 1761-1771. [CrossRef]

38. An, X.; Baker, P.; Li, H.; Su, J.; Yu, C.; Cai, C. The patterns of bacterial community and relationships between sulfate-reducing bacteria and hydrochemistry in sulfate-polluted groundwater of Baogang rare earth tailings. Environ. Sci. Pollut. Res. 2016, 23, 21766-21779. [CrossRef]

39. Amils, R. Lessons learned from thirty years of geomicrobiological studies of Río Tinto. Res. Microbiol 2016, 167, 539-545. [CrossRef]

40. Baker, B.J.; Banfield, J.F. Microbial communities in acid mine drainage. FEMS Microbiol. Ecol. 2003, 44, 139-152. [CrossRef] 
41. Sun, W.; Sun, X.; Li, B.; Xu, R.; Young, L.Y.; Dong, Y.; Zhang, M.; Kong, T.; Xiao, E.; Wang, Q. Bacterial response to sharp geochemical gradients caused by acid mine drainage intrusion in a terrace: Relevance of $\mathrm{C}, \mathrm{N}$, and $\mathrm{S}$ cycling and metal resistance. Environ. Int. 2020, 138, 105601. [CrossRef] [PubMed]

42. Johnson, D.B.; Bridge, T.A.M. Reduction of ferric iron by acidophilic heterotrophic bacteria: Evidence for constitutive and inducible enzyme systems in Acidiphilium spp. J. Appl. Microbiol. 2002, 92, 315-321. [CrossRef]

43. Xu, R.; Li, B.; Xiao, E.; Young, L.Y.; Sun, X.; Kong, T.; Dong, Y.; Wang, Q.; Yang, Z.; Chen, L.; et al. Uncovering microbial responses to sharp geochemical gradients in a terrace contaminated by acid mine drainage. Environ. Pollut. 2020, 261, 114226. [CrossRef]

44. Druschel, G.K.; Baker, B.J.; Gihring, T.; Banfield, J.F. Acid mine drainage biogeochemistry at Iron Mountain, California. Geochem. Trans. 2004, 5, 13-32. [CrossRef]

45. Coupland, K. A Study of the Geomicrobiology of Acid Mine Drainage Impacted Environments. Ph.D. Thesis, University of Wales, Bangor, UK, 2006.

46. Xu, R.; Sun, X.; Häggblom, M.M.; Dong, Y.; Zhang, M.; Xiao, E.; Xiao, T.; Gao, P.; Li, B.; Sun, W. Metabolic potentials of members of the class Acidobacteriia in metal-contaminated soils revealed by metagenomic analysis. Environ. Microbiol. 2021, 23. [CrossRef]

47. Kimura, S.; Bryan, C.G.; Hallberg, K.B.; Johnson, D.B. Biodiversity and geochemistry of an extremely acidic, low-temperature subterranean environment sustained by chemolithotrophy. Environ. Microbiol. 2011, 13, 2092-2104. [CrossRef]

48. Foster, A.L.; Munk, L.; Koski, R.A.; Shanks, W.C., III; Stillings, L.L. Relationships between microbial communities and environmental parameters at sites impacted by mining of volcanogenic massive sulphide deposits, Prince William Sound, Alaska. Appl. Geochem. 2008, 23, 279-307. [CrossRef]

49. Paustian, T.; Roberts, G. Deinococcus and Cytophaga. In Through the Microscope: A Look at All Things Small. 2007. Available online: http:/ / www.microbiologytext.com/6th_ed/ (accessed on 17 April 2020). 